\title{
Identity Declamation in Nigerien Oral Epic
}

\author{
Adamou Idé Oumarou (Corresponding author) \\ Faculty of Art and Human Sciences, Abdou Moumouni University, Niger \\ Email: adamouideoumarou83@yahoo.com
}

Received: $23 / 11 / 2020$

Accepted: 26/01/2021

Published: 01/03/2021

Volume: 2 Issue: 2

How to cite this paper: Oumarou, A. I. (2021). Identity Declamation in Nigerien Oral Epic.

Journal of Critical Studies in Language and Literature, 2(2), 42-46

DOI: https://doi.org/10.46809/jcsll.v2i2.58

Copyright (C) 2020 by author(s) and Global Talent Academy Ltd. This work is licensed under the Creative Commons Attribution International License (CC BY 4.0).

http://creativecommons.org/licenses/by/4.0/

\section{(c) (i)}

\begin{abstract}
This paper examines identity through the declamation of zamu or praise poetry in the oral epic narration of Moumouni Sékou, one of the Zarma (an ethnic group from Niger) bards or griots better known as Kulba Baaba Seebeeri. Right at the opening episode of the epic song, the bard proceeds to exhibit the identity of one of his heroic figures Haamali Seyni Gakoy by announcing some of his qualities or values such as: fearlessness, truthfulness, friendliness, gorgeousness and self-control to name but a few. In the eyes of the griot, these traits are key values that characterize the identity of the noble. The exhibition of these salient and important qualities is an interpellation of the griot toward his audience, so as to make them aware of the cultural moral values that past generations held individually and collectively.
\end{abstract}

Keywords: Oral Epic, Identity, Zamu or Praise Poetry, Cultural Moral Values, Zarma, Kulba Baaba

\section{Introduction}

To justify their arrival and settlement in Africa, the European missionaries qualified the Africans as peoples without "culture". According to Henri Lopès,

Two data have long been used against sub-Saharan Africa: the small number of monuments, the lack of libraries. The West has used this argument to justify its "civilizing mission" to the "savages" without culture. Since then, the label has not been easy to tear off and its pieces still stick to our skin. ${ }^{1}$ (qtd in Jacques Chevrier 1986, p. 7)

It is still true that "its pieces still stick to our skin", but while "cultural renewal" is regaining interest, managing cultural awareness, especially "identity", has become one of the central challenges of our period. In fact, the issue of identity is a current concern for researchers in the world in general, and in Africa in particular. I am interested in this theme because it focuses on cultural values that are likely to lead the people of a Nation to a change of mentality, which will enable them to face the stakes and challenges of development.

In this paper, I intend to study the contribution of the oral artist Moumouni Sékou to 'identity awareness'; I will show that by using zamu or praise song declamation, the oral artist incites his audiences to value their cultures. By choosing to work on 'identity', my purpose is to highlight positive cultural values, from Sekou's songs, that can be the pillars of development and well-being in Niger and in Africa. The theoretical support of this paper is an interdisciplinary approach based on a mix of linguistic, sociological, anthropological and literary perspectives. 
Identity is one of the best and dearest characteristics of a society. That is the reason why many researchers in disciplines, such as the ones mentioned above, have studied the issue of identity with great attention and huge interest. It was, nevertheless, very difficult for them to give a clear-cut definition of the concept of identity. The Longman Dictionary of Contemporary English, however, defines it as: "who or what a particular person or thing is". To this definition, we can add the one given by the Caribbean writer Emilia Ippolito, who refers to identity as "names we give to the different ways we are positioned by, and position ourselves within, ...” (2000, p. 19)

Contrary to the dictionary's definition that emphases the individual, that is to say, the person taken alone, the definition of Ippolito puts emphasis on the group. Consequently, from the two definitions given above we can deduce that the issue of identity is twofold. It can be both individual and collective. This vision seems to be shared by the griot Moumouni Sékou known as Kulba Baaba Seebeeri. In fact, Kulba Baaba talks about both the individual and the group in his compositions. But he puts much more emphasis on individual identity.

Contrary to the dictionary's definition that emphases the individual, that is to say, the person taken alone, the definition of Ippolito puts emphasis on the group. Consequently, from the two definitions given above we can deduce that the issue of identity is twofold. It can be both individual and collective. This vision seems to be shared by the griot Moumouni Sékou known as Kulba Baaba Seebeeri. In fact, Kulba Baaba talks about both the individual and the group in his compositions. But he puts much more emphasis on individual identity.

\section{Zamu Declamation as Individual Identity through the Third Person Narrative Voice}

Zamu is referred to as praise song. Most of the time, zamu consists in praising the individual, but sometimes the object of the zamu can be an animal, a thing or an event as Stephen Belcher suggested:

The term [praise poetry, that is, zamu in Zarma] is applied to hymns of praise to deities, to the invocations of animals slain in the hunt, to the warrior's shrill proclamation of his deeds, to a bride's description of her beauty and skills, and to the collection of allusive references to the deeds of the ancestors of a given clan. (Belcher, 1999, p. 16-17).

It is not important what its object is; the zamu can be of many varieties. According to Belcher,

Praise songs of all varieties share in the creative power of languages. In essence, the praise poem involves the creation and application of names for an individual (or other being) and draws on a repertoire of traditional formulations and allusive references; the genre depends in a sense on the magic ... of names and identity. (1999, p. 17)

Thus, to recall his identity, the individual may proclaim his own zamu, as highlighted by Belcher above when he talks about "the warrior's shrill proclamation of his deeds" and the "bride's description of her beauty and skills". However, in the Songhay-Zarma (Kulba Baaba's ethnic group and language of epic poetry composition and performance) area, proclaiming zamu is neither the task of a bride nor that of a warrior. It is only in some rare cases that the warrior proceeds to do his own zamu. One example of these rare cases can be on the battle field.

Even on the battle field, at the presence of his griot, the warrior should not act so as to proclaim his own catchwords. It is up to the griot of the warrior to do his zamu. This is so, because, as in the other societies (Peulh, Hausa to name but a few), in the Songhay-Zarma society too, every person has a role to play in order to contribute to the well-being of the community. This system of role-play subdivision classes the warrior among the nobles or élites who are the leaders and decision makers of the community.

Furthermore, the same system of role-play subdivision classes the griot among the group of subjects who are at the service of the nobles. According to Jan Vansina (1985, p. 37) griots are "professional and casted praise singers and tellers of accounts". They are in charge of praising the nobles in order to encourage them and remind them the great achievements of their forefathers. The nobles in return must be large toward the griots because, as mentioned by Diouldé Laya and Jeanne Bisilliat in their book, La Tradition Orale dans la Société Songhay-Zarma: Les Zamu ou Poèmes sur les Noms: “...power needs any exhibition... the one who holds it should, if he wants to keep his reputation, be generous and large”. (1972, p. 27).

The praise provides satisfaction to the noble for the simple reason that it reminds him of his identity. In case the noble recognizes himself in the words of the griot, he is able to offer him gifts sometimes unimaginable.

Rightly, in some extent, the action of praise aims at boosting the nobles so as to give the better of their own. In the eyes of Belcher, "Praise songs are one of the keys to the relations between griots and nobles" (1999, p. 11). It aims at reminding the nobles of their burkinatarey, that is, their nobleness. The griot or bard who is a master in the art of speaking is one of the key driving elements of this process in the sense that he has the genius to remind the nobles their responsibilities.

In the songahy-zarma society, there are famous griots such as Tinguizi Mabé, Djado Sékou, Badjé Bangna, Djalba Dialba Badjé, Karimou Saga and Kulba Baaba to name but a few. The griot of our concern is Kulba Baaba who is considered as the most senior member of the contemporary Zarma griots. Talking about him among the well-known jasare of recent years, Bornand writes: 
The oldest of them is Koulba Baba, whose real name is Moumouni Sékou. Born in 1899 in Sébéri in the Kouré canton ([today department] of Kollo), he died in Niamey in 1975. Both his father and his mother were of jasare origin. If he first learned his trade from a paternal uncle, he then went to Cote-d'Ivoire and Mali to meet the great Malian griot, Bansouma Cissoko. (2005, p. 222-223)

As seen earlier, the griot has the qualification of praising the noble. He also has the qualification of reminding people approximately about their parents or ancestors and about their different exploits. So, apart from the art of speaking, the griot also has the knowledge of the genealogy of the members of the society. Belcher stated that "Griots are thus the repositories of family fame. They control social identities." (1999, p.12)

In addition, the art of panegyric knowledge confers to the bard a certain advantage in terms of identity concerns. Most of the time the griot claims that he knows all the families and the family trees of every family in his village. This skillful knowledge allows him to have the capacities to praise people individually and collectively as Belcher supports:

...the power exercised by griots is that of Word. They remember and recall the praises, the genealogy, and the history of the clan of their noble patron(s). A griot will not be limited to one family but will know many. (1999, p. 11-12).

The griot knows many families and he is able to praise each family member accordingly. In the case of Kulba Baaba, he talks about the individual when he reminds a person his own qualities through his motto or catchwords among other members of the society. Kulba Baaba uses the zamu to praise the individual by using his name so as to galvanize this person in order to make him responsible in front of his tasks. He acts so because he knows that -as pointed out by Laya and Bisilliat- "words give an intensified force to the essence of the name and the name is the person". (1972, p. 15)

The effect of the intensified power of the words on the name can be aptly illustrated by the epic poem of Soumeylou Gakoye. In fact, in this long poem, Kulba Baaba started his poetic narration with the motto (catchwords) of Hamaali Seyni Gakoy which begins as follow:

\begin{tabular}{|l|l|}
\hline A ne nga Hamaali Seyni Gaakoy & [He said that, he] Hamaali Seyni Gaakoy \\
\hline Nga si humburu & He is not afraid \\
\hline Nga si tangari & He never ever tells lies \\
\hline Nga si ywa nga hinne & He is not a greedy person who eats alone \\
\hline Nga si canse & He is not a jealous person \\
\hline Nga si wayboro zaara ka a ga koonu zaari. & $\begin{array}{l}\text { He does not remove a woman's garment in } \\
\text { daytime. }\end{array}$ \\
\hline
\end{tabular}

(Mounkaila, 2008, p. 34)

It is true that along the story, Kulba Baaba slips occasionally into other voices, but in this opening passage, he recounts his account in the third person voice. All the above introductory six lines begin with the third person singular 'he'. All of them refer to Hamaali Seyni Gakoy and they all highlight his identity. This technique of using the third person "he", allows the griot to substitute himself with the person of the hero. By doing so, Kulba Baaba manages to let the hero proclaiming his own zamu in front of the audience.

Thus, for the audience, it is as if the hero is present and he is the one who is talking directly. It is as if the image of the griot performer vanishes, and the audience only sees who the personae become de facto instead. This technique proper to narrative devices is frequently used in the epic poems of Kulba Baaba. It also permits the griot to challenge each member of the society, individually speaking.

For the griot, avoiding naming the hero by his own name and replacing the name by the third person 'he' is somehow a manner of saying that the hero can be every member of the community. In such, all the qualities of the hero can be the qualities of everyone. The same way all the vices of the hero can be the vices of everyone. So, in the eyes of Kulba Baaba, it is a challenge for everyone to cultivate values that are good for the construction of society where it is fine to live, one hand, and on the other hand the challenge consists in avoiding any behavior that can endanger the well-being of the community.

It is the reason why while proclaiming the zamu of Hamaali Seyni Gakoy, his name is mentioned only once and even then, the verse where the name is mentioned starts with the personal pronoun 'he' instead of the real name. The true name is mentioned at the end of the verse: "He said that, he, Hamaali Seyni Gaakoy". Apart from that, no quality of Hamaali Seyni Gaakoy is mentioned in this very verse where the name is given. The griot intentionally proceeds that way to show that truly his hero is Hamaali Seyni Gaakoy but in some extent he may be 'everyone'.

\section{Zamu and Moral Cultural Values}

Because the hero may be 'everyone' in the community, all the verses ( 2 to 5 ) that begin with the pronoun 'he' without the true name of the hero contains contain some qualities that, for the griot, should be found in everyone in the group. The verse two deals with the quality of courage: "He is not afraid". Hamaali Seyni Gaakoy is not a coward man. He is a courageous 
warrior. Bravery is one of the qualities every warrior should have. The value of fearlessness is one of the characteristics of a hero. It is as if the griot is calling each participant to the performance declamation to be like his hero. Like the hero, each member should not fear anything. Everyone should be brave.

After bravery, in the declamation of the identity of Gaakoy, another quality among the qualities is truthfulness. In the conception of the griot, a noble does not tell lies. He always tells the truth even if his life depends on telling it. It is this quality that, according to the griot, should animate each particular person in the community: "He never ever tells lies". Being truthful is a quality required for any in the society. If the person is not truthful then he does not deserve the trust of his peers. In other words, whosoever inspires to be a leader should be trustworthy. Trustworthiness and truthfulness are always linked. They go together. If the first is lifted, the second will not stay.

One more quality mentioned by the griot in his account is that of magnanimity in verse four: "He is not a greedy who eats alone". Naturally, the bard likes a greedy less person because of his largess. The bard hates the stingy men who keep everything for themselves. So, a large person never eats alone. He always shares with the others so as to be perfect and useful as supported by Laya and Bisilliat:

It is noticeable in these zamu that the power of poetic admiration, and maybe, imagination take back their rights, that these handsome and gorgeous men are accomplished, and what a wonderful magnificence. (1972, p. 29)

The quality of friendliness is essential in the life of the community. Avoiding greediness is a quality that allows the poor people to feel comfortable in the society. In fact, in a milieu where people share, misery or hardship diminishes. In the process of sharing, both the giver and the receiver feel a certain feeling of satisfaction. The giver is proud to render a service to his like and the receiver is delighted to see his burden appeased.

The last but one quality enumerated by the griot in his story is gorgeousness: "He is not jealous". The hero is not jealous in the sense that he is not covetous of the possessions of the others. Through this passage, the griot is encouraging the audience to have their own possessions instead of envying someone due to his material possessions. Of course, it is not forbidden to envy someone who is successful if the fact is to copy him so as to be successful like him. But, if the jealousy consists in seeing the destruction of the others, then it becomes a vice that should be avoided.

The last quality developed by the griot is self-control: "He does not remove a woman's garment daily". The only moment the hero takes woman's clothes out is in the night. In the by gone days, staying home daily especially in one's house is considered as cowardice. It is also seen as indecent for the day is a moment for hard working not a moment for enjoying one's bed. Complete man should go out early in the morning and come back home late in the afternoon if not completely in the evening. Staying home day and night is reserved for women only. Any man who acts so is considered like a woman. It is for this reason that early in their young ages' boys are taught not to stay home daily but go out to toil instead.

The analysis of the opening six lines of the epic song of Sumailu Gakoy shows that Kulba Baaba portrays a revalorized identity of a typical noble figure. Through the declamation of the zamu of Hamaali Seyni Gaakoy, many cultural moral values tightly linked to the identity of Seyni Gaakoy are mentioned. For Kulba Baaba, by definition a noble is someone who has all the cultural moral values discussed above. Unfortunately, nowadays these qualities tend to disappear.

The griot realized this sudden change and decided to bring his contribution in order to re-establish the lost values. For him, the disintegration of the society somehow began with colonialism. The moral decay observed in contemporary society does not exist before the arrival of the colonizers. But it is not too late to look to the future for salvation and to relieve society of apathy, cynicism, moral degeneracy, and inertia for,

It cannot be stressed enough that a civilization of orality, like all others, is in an attitude of constant vigilance with regard to what it has been or what it believes it has been. This is, for it, the way to settle the question of its identity in the present, and to project its dreams into the future. (Diane, 2005, p. 275)

The contribution of the griot in some extent, consists in reminding the individual the values of his forefathers in the past. The same values that made them famous and upstanding in the remote past, are in the eyes of the bard the same qualities that can change the unrecognized self of today. This body who has been changed by the system of imperialism, for example, which tends to be an egoist system where the personal interests prevail over the common interest. So, for the griot, the individual of the past, that is to say, before the arrival of imperialist system, is a good charitable person. But, the events of imperialism and colonialism and their corollaries transform him in a person different from his forefathers in terms of values. A person referred to by Madhu Krishnan as person who lost his origin with: "a complete loss of identity under the psychic trauma of colonization." (2014, p. 44)

The griot also thinks that it is possible to become again a very good person. For him, following the examples of those who marked the history is one of the best ways to reborn and be like these historical figures. It is by developing the same qualities developed by these heroes that today, in a globalized world, the individual can become a person who deserves all the respect of the others. Solidarity is one of the main characteristics of our forefathers. Nowadays, this core quality tends to vanish both in the cities and rural areas. 
If in the past a man is ashamed of betraying his fellow comrade, it is because he has in mind the idea that he should respect him as he himself would like to be respected. And if today the same individual is not ashamed of committing the same blemish, it is because he forgets the behavior of his parents and disconnects himself with these good behaviors. If again another person finds pleasure in the problems of his friend, it is because he puts aside the true meaning of friendship which in the eyes of elders is sometimes stronger than some kinship relations.

In brief, it seems that the griot values more the individual traits than the group ones in the zamu. That is because the griot wants every single person in the society to be particular. Particular in the sense that he will be able to sustain himself without bothering anybody else (maybe that is the reason why the profession of griot tends to disappear). The griot points out the fact that for a society to prosper, each member should be courageous individually speaking. He proceeds to exhibit the identity of Haamali Seyni Gakoy through his cultural moral values. This is an interpellation by the griot toward his audience to be aware about these values that foster the past generations. So, in most cases, zamu and epic are inseparable as aptly illustrated by Belcher:

\begin{abstract}
Also called panegyric, praise poetry is generally incorporated in epic in Africa. "The two genres are rigorously separated in the poetics of the European literary tradition. In Africa the division is less clear. Clan or lineage poems and songs of praise necessarily evoke clan history and the celebrated individuals of the past. The praise song may sometimes tell a story, as would an epic, although allusion and indirect reference are the typical tropes of panegyric. Further, praise songs are incorporated into epics in varying degrees, and they appear inextricable from certain aspects of epic performance. $(1999$, p. 16)
\end{abstract}

In the case of Zarma oral epic, especially in Zarma epic poetry, almost all the poems celebrate the identity of Zarma people through the heroic achievements of the main hero.

\title{
4. Conclusion
}

To sum up, we can say that the vision of Moumouni Sékou as far as identity is concerned is twofold. It is both individual and collective with emphasis puts on the individual one. Individual identity refers to the identity of a single person whereas collective identity refers to the identity of the whole members of the society or the community. The declamation of individual identity is done through zamu. As for the declamation of collective identity it is done through the entire epic. The aim of the griot is to create an environment in the society where each member knows his individual and collective responsibilities and acts for the well-being of the community.

\section{References}

Belcher, S. P. (1999). Epic traditions of Africa. Indiana University Press.

Bisilliat, J. and Laya, D. (1972). Tradition orale dans la société songhay-zarma: Les zamu ou poème sur les noms. CNRSH.

Bornand, S. (2005). Le discours du griot généalogiste chez les Zarma du Niger. Karthala.

Chevrier, J. (1986). L'arbre à palabres : Essai sur les contes et récits traditionnels d'Afrique noire. Hatier.

Diagne, M. (2005). Critique de la raison orale : Les pratiques discursives en Afrique noire. Karthala ; Centre d'études linguistiques et historiques par tradition orale ; Institut fondamental d'Afrique noire.

Ippolito, E. (2000). Caribbean Woman Writers. Identity and Gender. Camden House.

Krishnan, M. (2014). Contemporary African Literature in English: Global Locations, Postcolonial Identifications. Palgrave Macmillan.

Longman Dictionary of Contemporary English (New Edition). (1989).

Mounkaila, F. (2008). Anthologie de la littérature orale songhay-zarma : Saveurs sahéliennes. L'Harmattan.

Vansina, J. (1985). Oral Tradition as History. Heinmann Kenya.

\section{Endnotes}

\footnotetext{
${ }^{1}$ All translations are mine unless otherwise indicated.
} 